\title{
VALUE OF CEREBROSPINAL FLUID TUMOR NECROSIS FACTOR-ALPHA (TNF-ALPHA) FOR RAPID DIAGNOSIS OF BACTERIAL MENINGITIS
} By

\author{
IMAN FAWZY MONTASSER', EMAN MOHAMED EL-GINDY', ENAS HASSAN AL- \\ LAM ${ }^{1}$, HOSAM S. ELBAZ ${ }^{2}$, REHAM ALI AHMED KHALIFA ${ }^{3}$ \\ AND HANY EL SAYED ALI ${ }^{4}$
}

Departments of Tropical Medicine ${ }^{1}$, Internal Medicine ${ }^{2}$, Microbiology and Immunology ${ }^{3}$, Faculty of Medicine, Ain Shams University ${ }^{1,2,3}$, Cairo $11566^{3}$ and Embaba Fevers Hospital ${ }^{4}$, Giza, Egypt

Abstract

Meningitis is common in tropical areas and also in Egypt and has a world-wide distribution This study evaluated the potential role of CSF TNF $\alpha$ in diagnosis and differential diagnosis of acute meningitis (bacterial versus aseptic meningitis). This case-control study was conducted between Ain Shams University Tropical Medicine Department and Embaba Fever Hospital. Fifty patients with suspected meningitis were recruited during from January 2014 to June 2014. They were divided according to culture results into 2 groups: GI: 40 patients with acute bacterial meningitis (proved by CSF culture), G2: 10 patients matched according to age and sex with clinical sings of CNS infection but without laboratory evidence of bacterial origin, (Suspected cases, and negative culture). Both groups were subjected to thorough history taking, full clinical examination, and laboratory investigations including CSF analysis \& CSF TNF was measured by ELISA.

The results showed a highly significant difference between cases and control regarding CSF TNF ( $\mathrm{P}=0.00)$. The criteria's of diagnostic validity test was $100 \%$ for all at cutoff $\geq 275 \mathrm{ng} / \mathrm{ml}$ and $\leq 700 \mathrm{ng} / \mathrm{ml}$ with $100 \%$ specificity and sensitivity. A significant correlation between CSF-TNF and each of ESR $(\mathrm{P}=0.003)$ \& CSF cells $(\mathrm{P}=0.015)$, without significant correlation regarding other parameters $(\mathrm{P}>0.05)$.

Keywords: Bacterial meningitis, aseptic meningitis, tumor necrosis factor

\section{Introduction}

Meningitis is common in tropical areas and also in Egypt and has a world-wide distribution. Meningitis is inflammation of the protective membranes covering the brain and spinal cord, known collectively as the meninges. The inflammation may be caused by infection with viruses, bacteria, or other microorganisms, and less commonly by certain drugs (Ginsberg, 2004). Meningitis can be life-threatening because of the inflammation's proximity to the brain and spinal cord; therefore the condition is classified as a medical emergency (Sáez-Llorens and McCracken, 2003; Tunkel et al, 2004). The commonest symptoms of meningitis are headache and neck stiffness associated with fever, confusion or altered consciousness, vomiting, and an inability to tolerate light, photophobia (Van de Beek et al, 2006). The classic triad of diagnostic signs consists of nuchal rigidity, sudden high fever and altered mental status; In infants up to 6 months of age, bulging of the fontanelles might be present (Theilen et al, 2008). Cerebrospinal fluid (CSF) analysis is the cornerstone and diagnostic test of choice for suspected meningitis. Measure the opening pressure and send the fluid for cell count (and differential count), chemistry (i.e., CSF glucose and protein), and microbiology (i.e., Gram stain and cultures). However, lumbar puncture is often delayed or deferred owing to concern about the risk of cerebral herniation, which might be over emphasized (Scarborough and Thwaites, 2008).

Meningitis is defined as bacterial according to CSF laboratory findings [(increased protein $>100 \mathrm{mg} / \mathrm{dl}$, decreased glucose $<40 \mathrm{mg} / \mathrm{dl}$, leukocyte count $100-5000 / \mathrm{mm} 3$ with polymorph nuclear leukocyte domination $>80 \%$ ), and identification of agents in Gram staining, and/or positive bacterial culture. The $\mathrm{CSF} /$ serum glucose ratio $\leq 0.4$ was indicative of bacterial meningitis (Straus et al, 2006).

Before CSF bacterial cultures were available, most patients with acute meningitis were treated with broad spectrum antibiotics 
targeting bacterial meningitis. This did not seriously harm aseptic meningitis patient; however, it may enhance the local frequency of antibiotic resistance (Wise et al, 1998), caused antibiotic adverse effects, nosocomial infections (Raymond, 2000) and high medical costs (Parasuraman et al, 2001). Thus, it was not only important to recognize bacterial meningitis patients who promptly need antimicrobial therapy but also aseptic meningitis patients who did not need antibiotics and/or hospital stays (Huy et al, 2010).

Clinical criteria, Gram staining, bacterial antigen testing of CSF and the classic biological markers in blood (CRP level, WBC count, and neutrophil count) or CSF (protein level, glucose level, WBC count, \& neutrophil count) used alone did not offer $100 \%$ sensitivity and specificity to distinguish bacterial and aseptic meningitis (Dubos et al, 2008). Gram staining of the sample may demonstrate bacteria in bacterial meningitis, but absence of bacteria does not exclude bacterial meningitis as they were in $60 \%$ of cases; this figure was reduced by a further $20 \%$ if antibiotics were administered before taking the sample (Tunkel et al, 2004). Waiting for at least 2 days was recommended to identify bacterial growth in CSF cultures, and the period was 3-8 days for viral cultures (Cassady and Whitley, 1997). Besides, identifying the frequently encountered viral agents via PCR is always impossible in every institution (Oberhoffer et al, 1999). Because consequences of delayed diagnosis could be severe, any proposed tool must be near 100\% sensitivity (Dubos et al, 2008). So, intensive research was carried out to find new and rapid diagnostic methods for differential diagnosis of bacterial and viral meningitis.

Tumor necrosis factor (TNF, cachexin, and formerly known as $\mathrm{TNF} \alpha$ ) is a cytokine involved in systemic inflammation and a group of cytokines that stimulate the acute phase reaction, produced chiefly by activated macrophages, although it could be produced by many other cell types as CD4+ lymphocytes, NK cells and neurons. The TNF primary role is regulation of immune cells. TNF as an endogenous pyrogen could induce fever, apoptotic cell death, sepsis (through IL1 \& IL6 production), cachexia, and inflammation and to inhibit tumorigenesis and viral replication.

This study aimed to evaluate the potential role of CSF TNF- $\alpha$ in diagnosis and differential diagnosis of acute meningitis (bacterial versus aseptic meningitis).

\section{Patients, Materials and Methods}

This case-control study was conducted between Tropical Medicine Department-Ain Shams University and Embaba Fever Hospital. Patients with suspected meningitis were recruited from January 2014 to June 2014.

A total of 50 patients presented to emergency unit of Embaba Fever Hospitals with suspected acute meningitis were enrolled. They were divided after culture results into 2 groups: GI: 40 patients with acute bacterial meningitis (CSF culture). G2: 10 patients matched according to age and sex with clinical sings of CNS but without evidence of bacterial origin (suspected cases, negative culture). Cases with negative culture were excluded to validate TNF- $\alpha$ as a marker against gold standard (culture).

Inclusion criteria: Patients presented for the first time to Embaba fever hospital with clinical picture and CSF analysis suggesting acute meningitis. Exclusion criteria: a- Antibiotic treatment before admission, more than 2 consecutive days (Viallon et al, 2011), bClinical and laboratory findings suggesting tuberculous or cryptococcus meningitis, cClinical picture suggestive of cerebro-vascular disease, d- Brain tumors or other neurological insults, e- Other causes of fever (another site of infection beside meningitis), $\mathrm{f}$ Other causes of coma, and g- Drug-induced meningeal irritation as intravenous immunoglobulins, azathioprine, methotrexate...etc.

Ethical considerations: This study was approved by the Research and Ethics Committee of Ain Shams University, according to local research governance requirements. All 
participants approved to share in accordance with the ethical standards laid down in the 1964 Declaration of Helsinki and all subsequent revisions. The objectives were explained to those met pre-designed inclusion criteria and signed an informed consent form.

Study tools: All cases were subjected to the following: a- Full medical history: with special emphasis on the presence or absence of the classic triad of meningitis diagnostic symptoms (headache, fever \& projectile vomiting), abnormal movements, impairment of consciousness and antibiotic treatment. Thorough clinical examination of all systems including nervous system with stress on classic triad of diagnostic signs of meningitis; nuchal rigidity, positive kernig's sign and brudzinski's sign, level of consciousness, presence or absence of rash and convulsions.

Laboratory tests: a- CBC, ESR and CRP, b- liver function tests (ALT, AST), c- kidney function tests (urea, creatinine) and drandom blood glucose.

Specific laboratory tests: 1- CSF analysis: a- Physical examination: color, aspect \& pressure, b- Chemical examination: protein and glucose, c- Cell count: total and differential leukocytic count, d- Gram's stain and culture, and e- $\mathrm{CSF} /$ serum glucose ratio. Meningitis is defined as bacterial according to CSF (increased protein $>100 \mathrm{mg} / \mathrm{dl}$, decreased glucose $<40 \mathrm{mg} / \mathrm{dl}$, leukocyte count $100-5000 / \mathrm{mm}^{3}$ with polymorph nuclear leukocyte domination $>80 \%$ ), identification of bacterial agents in Gram staining, and/or positive bacterial culture, $\mathrm{CSF} /$ serum glucose ratio $\leq 0.4$ as an indicative (Straus et al, 2006). 2- CSF-TNF- $\alpha$ was measured for all participants by ELISA technique.

Test principle: Human TNF alpha PicoLi $n e^{\mathrm{TM}}$ ELISA Kit (Boster Biologics, USA) using standard sandwich ELISA technology. A TNF $\alpha$ specific mouse monoclonal antibody was pre-coated onto 96- well plates.

Assay procedure: Standard TNF $\alpha$ detection curve was prepared by adding $0.1 \mathrm{ml} /$ well of $1000 \mathrm{pg} / \mathrm{ml}, 500 \mathrm{pg} / \mathrm{ml}, 250 \mathrm{pg} / \mathrm{ml}$, $125 \mathrm{pg} / \mathrm{ml}, 62.5 \mathrm{pg} / \mathrm{ml}, 31.2 \mathrm{pg} / \mathrm{ml}, 15.6 \mathrm{pg} / \mathrm{ml}$ human $\mathrm{TNF} \alpha$ standard solutions into precoated 96 -well plate. $0.1 \mathrm{ml}$ of sample diluent buffer was added into control well (Zero well) and $0.1 \mathrm{ml}$ of each properly diluted CSF sample to empty pre-coated test wells and incubated at $37^{\circ} \mathrm{C}$ for $90 \mathrm{~min}$. The $0.1 \mathrm{ml}$ of biotinylated anti-human TNF $\alpha$ antibody working solution was added to each well \& incubated at $37^{\circ} \mathrm{C}$ for $60 \mathrm{~min}$ followed by washing three times with phosphate buffer saline (PBS). $0.1 \mathrm{ml}$ Avidin-Biotin-Peroxidase Complex (ABC) working solution was added to each well and incubated at $37^{\circ} \mathrm{C}$ for $30 \mathrm{~min}$, and then unbound conjugates were washed with PBS. Horseradish peroxidase (HRP) substrate, 3,3',5,5'-tetramethylbenzidine (TMB) was used to visualize HRP enzymatic reaction. TMB as a chromogen yielded a blue color when oxidized by HRP. $90 \mu \mathrm{l}$ of prepared TMB color developing agent was added to each well and incubated at $37^{\circ} \mathrm{C}$ in dark for $25-30 \mathrm{~min}$. HRP activity produced a blue color changed into yellow after adding $0.1 \mathrm{ml}$ of acidic stop solution. O.D. absorbance was read at $450 \mathrm{~nm}$ in a microplate reader within 30 min after adding stop solution. The yellow density was proportional to human TNF $\alpha$ amount of sample captured in plate.

Results calculation: Relative O.D.450= O.D.450 of each well-O.D.450 of Zero well. Standard curve was plotted as relative O.D. 450 of each standard solution (Y) vs. respective concentration of standard solution (X). Human TNF $\alpha$ concentration of samples was interpolated from standard curve.

Statistical analysis: IBM SPSS statistics (V. 22.0, IBM Corp., USA, 2013) was used. Data were expressed as median and percentiles for quantitative non-parametric measures and to number and percentage for categorized data

\section{Results}

Demographic features showed that 28 men $(70 \%) \& 12$ women $(30 \%)$ with ages ranged from 18 to 55 years in G1. In G2 (controls) included 8 men (80\%) and $2(20 \%)$ women with ages ranging from 22 to 52 years, with- 
out significant difference between both as regard age, sex and residence $(\mathrm{P}>0.05)$.

Fever was a constant in $95 \%$ of patients with bacterial meningitis \& $100 \%$ with aseptic meningitis, with significant difference in convulsion between groups $(\mathrm{P}<0.05)$ without significant difference as to other signs and symptoms (Tab. 1). A high significant difference in WBCs count, polymorph $\%$ \& lymphocytes $\%$ between groups $(\mathrm{p}=0.001)$ without significant difference in hemoglobin $\&$ platelets count $(\mathrm{P}>0.05)$, a high significant difference in serum levels of CRP and $\mathrm{ESR}(\mathrm{P}=0.002 ; 0.021)$ respectively (Tab. 2$)$.

CSF analysis showed significant difference as to aspect and color of CSF between groups $(p=0.00)$. CSF aspect was turbid or hazy in $90 \%$ of patients with whitish color in $75 \%$. In G2 CSF aspect was clear in $90 \%$ and colorless in $90 \%$ of patients (Tab. 3). A high significant difference was in WBCs, polymorph $\%$, lymphocytes $\%$, CSF protein, CSF glucose \& CSF/serum glucose ratio between groups $(\mathrm{P}<0.001)$. G1 showed increased CSF WBCs, polymorph predominance, CSF protein elevated, CSF glucose reduced and $\mathrm{CSF} /$ serum glucose ratio $\leq 0.4$. G2 showed increased mononuclear cell pleocytosis with nearly normal CSF glucose, normal or mild elevated CSF protein and CSF/ serum glucose ratio $>0.4$ suggestive of nonbacterial causes; viral or aseptic meningitis (Tab. 4). There was no significant difference as to CSF Gram stain between groups. Sixteen patients from G1 were Gram positive stain; 7 with St. pneumonia (43.75\%), 5 with $H$. influensae (31.25\%), one with Klebsiella $(6.25 \%)$, one case with Nisseria $(6.25 \%)$, and two with Staph aureus (12.5\%), gram stain in control was negative.

The culture yielded 22 cases with St. pneumonia (55\%), 12 cases with $H$. influensae (30\%), 2 cases with Klebsiella (5\%), one case with Nisseria (2.5\%) and 3 cases with Staph aureus $(7.5 \%)$ in $\mathrm{G} 1$, in G2 cultures were negative. A highly significant difference between groups as regards to CSF TNF $(\mathrm{P}=0.000)$. Diagnostic validity test criteria was $100 \%$ for all at cutoff more than $275 \mathrm{ng} /$ $\mathrm{ml}$ and less than $700 \mathrm{ng} / \mathrm{ml}$ with $100 \%$ specificity and sensitivity (Tab. 5). There was a significant between CSF-TNF \& each of ESR $(\mathrm{P}=0.003)$ \& CSF cells $(\mathrm{P}=0.015)$, but no significant with other parameters $(\mathrm{P}>0.05)$.

\begin{tabular}{|c|c|c|c|c|c|c|}
\hline \multirow[b]{2}{*}{ Manifestations } & \multicolumn{2}{|c|}{ G1 $(n=40)$} & \multicolumn{2}{|c|}{ G2 $(n=10)$} & \multirow[t]{2}{*}{$\chi^{2}$} & \multirow[t]{2}{*}{$P$ value } \\
\hline & no & $\%$ & no & $\%$ & & \\
\hline Fever & 38 & $95 \%$ & 10 & $100 \%$ & 1.026 & .311 \\
\hline Headache & 28 & $70 \%$ & 7 & $70 \%$ & 1.905 & .168 \\
\hline Vomiting & 30 & $75 \%$ & 7 & $70 \%$ & .000 & 1.000 \\
\hline Convulsions & 12 & $30 \%$ & 1 & $10 \%$ & 4.329 & $.037 *$ \\
\hline Photophobia & 3 & $7.5 \%$ & 0 & $0 \%$ & .798 & .372 \\
\hline Hallucination & 2 & $5 \%$ & 2 & $20 \%$ & 2.057 & .151 \\
\hline \multirow{3}{*}{$\begin{array}{l}\text { Consciousness: Alert } \\
\text { Consciousness: Semi-conscious } \\
\text { Consciousness: Coma }\end{array}$} & 2 & $5 \%$ & 1 & $10 \%$ & \multirow{3}{*}{4.882} & \multirow{3}{*}{.087} \\
\hline & 26 & $65 \%$ & 8 & $80 \%$ & & \\
\hline & 12 & $30 \%$ & 1 & $10 \%$ & & \\
\hline Neck rigidity & 26 & $65 \%$ & 7 & $70 \%$ & .476 & .490 \\
\hline Kerning's sign & 26 & $65 \%$ & 7 & $70 \%$ & .476 & .490 \\
\hline Brudhzinski's sign & 26 & $65 \%$ & 7 & $70 \%$ & .476 & .490 \\
\hline Skin rash & 3 & $7.5 \%$ & 0 & $0.0 \%$ & .798 & .372 \\
\hline
\end{tabular}

Table 2: Important Laboratory results of patients groups.

\begin{tabular}{|c|c|c|c|c|c|c|c|c|}
\hline \multirow[b]{2}{*}{ Test } & \multicolumn{3}{|c|}{ G1 $(n=40)$} & \multicolumn{3}{|c|}{$\mathrm{G} 2(\mathrm{n}=10)$} & \multirow{2}{*}{$\mathrm{Z}$} & \multirow[t]{2}{*}{$\mathrm{P}$ value } \\
\hline & Min. & Max. & Median & Min. & Max. & Median & & \\
\hline WBCs (cell/cmm) & 4.2 & 44 & 11.4 & 5.5 & 11.5 & 7.4 & -2.876 & $0.004 *$ \\
\hline Polymorph \% & 0.4 & 0.95 & 0.887 & 0.402 & 0.92 & 0.6565 & -3.249 & $0.001 *$ \\
\hline Lymphocytes \% & 0.04 & 0.585 & 0.0785 & 0.05 & 0.47 & 0.2875 & -3.381 & $0.001^{*}$ \\
\hline Platelets $(\mathrm{cell} / \mathrm{cmm})$ & 91000 & 647000 & 232500 & 102000 & 580000 & 327000 & -1.853 & 0.064 \\
\hline $\mathrm{Hb}(\mathrm{gm} / \mathrm{dl})$ & 7 & 13.8 & 10.75 & 6.7 & 13.4 & 10.4 & -0.352 & 0.725 \\
\hline Random blood glucose (mg/dl) & 56 & 198 & 118.5 & 55 & 174 & 107.5 & -0.487 & 0.626 \\
\hline Blood urea $(\mathrm{mg} / \mathrm{dl})$ & 10 & 85 & 24 & 10 & 34 & 19 & -2.283 & $0.022 *$ \\
\hline Serum creatinine $(\mathrm{mg} / \mathrm{dl})$ & 0.3 & 1 & 0.6 & 0.3 & 1 & 0.5 & -0.425 & 0.671 \\
\hline ALT (U/L) & 9 & 80 & 13 & 5 & 44 & 15 & -0.841 & 0.4 \\
\hline AST (U/L) & 13 & 112 & 18 & 14 & 45 & 25 & -1.776 & 0.076 \\
\hline CRP & 6 & 96 & 24 & 6 & 6 & 6 & -3.151 & $0.002 *$ \\
\hline ESR & 7 & 135 & 27.5 & 5 & 45 & 15 & -2.31 & $0.021 *$ \\
\hline
\end{tabular}


Table 3: Physical findings of CSF in patients groups

\begin{tabular}{|c|c|c|c|c|c|c|c|}
\hline \multirow{2}{*}{\multicolumn{2}{|c|}{ Test }} & \multicolumn{2}{|c|}{ G1 (cases) } & \multicolumn{2}{|c|}{ G2 (control) } & \multirow[b]{2}{*}{$\chi^{2}$} & \multirow{2}{*}{$P$ value } \\
\hline & & no & $\%$ & no & $\%$ & & \\
\hline \multirow{3}{*}{ Aspect } & Clear & 0 & $0.0 \%$ & 9 & $90.0 \%$ & \multirow{3}{*}{36.000} & \multirow{3}{*}{$.000 *$} \\
\hline & Hazy & 4 & $10.0 \%$ & 1 & $10.0 \%$ & & \\
\hline & Turbid & 36 & $90.0 \%$ & 0 & $0.0 \%$ & & \\
\hline \multirow{3}{*}{ Color } & Colorless & 0 & $0.0 \%$ & 9 & $90.0 \%$ & \multirow{3}{*}{36.250} & \multirow{3}{*}{$.000^{*}$} \\
\hline & Whitish & 30 & $75.0 \%$ & 1 & $10.0 \%$ & & \\
\hline & yellow & 10 & $25.0 \%$ & 0 & $0.0 \%$ & & \\
\hline
\end{tabular}

Table 4: Cytological and chemical findings of the CSF analysis in patients groups

\begin{tabular}{|l|c|c|c|c|c|c|c|c|}
\hline \multirow{2}{*}{ Test } & \multicolumn{3}{|c|}{ Group 1(n=40) } & \multicolumn{3}{c|}{ Group 2(n=10) } & \multirow{2}{*}{ Z } & P \\
\cline { 2 - 10 } value \\
\hline WBCs (cell/cmm) & Min. & Max. & Median & Min. & Max. & Median & & \\
\hline Polymorph \% & 500 & 17000 & 4000 & 37 & 500 & 200 & -5.408 & $0^{*}$ \\
\hline Lymphocytes \% & 0.7 & 1 & 0.95 & 0 & 0.6 & 0.2 & -5.449 & $0^{*}$ \\
\hline Protein & 0 & 0.3 & 0.05 & 0.4 & 1 & 0.8 & -5.449 & $0^{*}$ \\
\hline Glucose & 42 & 430 & 205.5 & 34 & 117 & 58 & -4.464 & $0^{*}$ \\
\hline CSF/serum glucose ratio & 0 & 144 & 2 & 31 & 93 & 65.5 & -4.229 & $0^{*}$ \\
\hline
\end{tabular}

Table 5: CSF TNF among patients groups.

\begin{tabular}{|l|l|l|l|l|l|l|l|l|}
\hline & \multicolumn{3}{|l|}{ G1 (cases) } & \multicolumn{2}{l|}{ G2 (control) } & Z & p-value \\
\hline \multirow{3}{*}{ CSF-TNF(ng/ml) } & Min. & Max. & Median & Min. & Max. & Median & \multirow{2}{*}{-4.854} & \multirow{2}{*}{$0.00 *$} \\
\cline { 2 - 10 } & 700 & 9000 & 4400 & 0 & 275 & 77.5 & & \\
\hline
\end{tabular}

\section{Discussion}

Bacterial meningitis is endemic in Egypt and sporadic cases occurring allover the year (Abdel Ghani et al, 2002). The delay in the diagnosis and the consequent delay in initiation of treatment can cause death in about $10 \%$ of cases with advanced disease and severe neurological sequelae as many as $80 \%$ of survivors (Van den Bos et al, 2005). It was important to distinguish bacterial meningitis from aseptic meningitis during the acute phase of the disease, as this could help to avoid complications and to limit unnecessary antibiotic use and hospital admissions (Tunkel et al, 2004). Clinical features of bacterial meningitis are nonspecific. Therefore, the discrimination of cases of bacterial meningitis from other causes by clinical feature alone is often impossible (Thwaites et al, 2005).

The presently used techniques have some limitations to diagnose or differentiate bacterial from viral meningitis (Tokuda, 2000). The CSF gram stain can be negative and misleading because of small number of organisms present in CSF or antibiotic therapy has been started, also, culture often require a delay of a day or more for growth and may be negative in partially treated cases (Abro et al, 2009). Therefore the identification of a discriminating parameter, which may lead to a rapid and accurate clinical test, would be of value in the differential diagnosis of acute meningitis.

In practice, before definitive CSF bacterial cultures are available, most patients with acute meningitis are treated with broad spectrum antibiotics targeting bacterial meningitis. In general, this did not seriously harm aseptic meningitis patient; but, it may enhance local antibiotic resistance (Wise et al, 1998), and cause antibiotic adverse effects, nosocomial infections (Raymond, 2000), and high medical costs (Parasuraman et al, 2001). So, it was important to recognize bacterial meningitis patients who promptly need antimicrobial therapy and aseptic meningitis patients who do not need antibiotics and/or hospital stays (Huy et al, 2010).

In the present study there was no significant difference in age and gender between groups $(p>0.05)$ with higher percentage of males than females. These results agreed with Østergaard and Benfield (2009), Tokuda et al. (2009), and Viallon et al. (2011).

Fever was noted in 38 patients $(95 \%)$ of 
bacterial cases and $100 \%$ of aseptic meningitis cases. This result was concordant with Østergaard and Benfield (2009), Elbishry et al. (2010) and Viallon et al. (2011). On the other hand, fever was not a universal with others (Gorse et al, 1998; De O Papaiordanu et al, 1999) who found fever in $59 \%$ \& $67 \%$ in patients' meningitis respectively, whose patients were $\geq 60$ years.

In the present study, there was no significant difference regarding symptoms and signs of septic and aseptic meningitis ( $p>$ $0.05)$, except for convulsion where there was significant difference between patients $(\mathrm{p}<$ 0.05). But, Viallon et al. (2011) found significant difference in headache and convulsion with higher percentages in bacterial meningitis. El- Kapany (2011) found no significant difference in photophobia. Elbishry et al. (2010) reported significant difference regarding skin rash in bacterial meningitis patients than those with aseptic meningitis.

In the present study there was no significant difference in blood glucose between patients groups $(\mathrm{P}>0.05)$. This result disagreed with El- Kapany (2011) and Viallon et al. (2011) who found significant difference in blood glucose between patients with bacterial meningitis and those with viral meningitis with lower values in bacterial meningitis. This might be attributed to administration of intravenous glucose infusion before admission or presence of diabetes mellitus.

In the present study, there was significant difference in CSF WBCs \& CSF polymorphs $\%(p<0.001)$ with higher values in bacterial meningitis. The results agreed others (Østergaard and Benfield, 2009; El- Kapany, 2011; Viallon et al, 2011). The increased CSF WBCs was attributed to increased blood brain barrier permeability caused by direct effect of bacteria and by response of immune system to the bacteria entrance with subsequent entrance of large numbers of WBCs into the CSF (SáezLiorens and McCracken, 2003).

In the present study, bacterial meningitis patients had a higher CSF protein than those of aseptic ones with high significant difference between them $(p<0.001)$. This result agreed with others (Østergaard and Benfield, 2009; Makoo et al, 2010; El- Kapany, 2011; Viallon et al, 2011). The elevated CSF protein in bacterial meningitis was attributed to the disruption and marked increased permeability of the blood brain barrier (Swartz, 2004) caused by the bacteria and by the immune system response to bacteria entrance in CNS (Sáez-Liorens and McCracken, 2003).

In the present study, there was a high significant difference in aspect and color of CSF between patients groups $(p<0.001)$. ElKapany (2011) reported high significant difference in aspect of CSF between patients with bacterial and aseptic meningitis. The cloudy CSF indicates higher levels of protein, white and red blood cells and/or bacteria, and may suggest bacterial meningitis (Tunkel et al, 2004).

In the present study, the patients of the bacterial group had a lower CSF glucose than those of the aseptic group with high statistically significant difference between them $(\mathrm{p}<0.001)$, which agreed with others (Østergaard and Benfield, 2009; Makoo et al, 2010; El-Kapany, 2011; Viallon et al, 2011). The hypoglycorrhachia characteristic of pyogenic meningitis was due to interference with normal carrier-facilitated diffusion of glucose and to increased utilization of glucose by host cells (Swartz, 2004).

In the present study, there was a high significant difference in $\mathrm{CSF} /$ serum glucose ratio between G1 \& G2 (p<0.001). This result agreed with Tokuda et al. (2009) and Viallon et al. (2011). But, Østergaard and Benfield (2009) reported no significant difference in $\mathrm{CSF} / \mathrm{serum}$ glucose ratio between patients with purulent meningitis of unknown etiology and those with lymphocytic meningitis.

In the present study, CSF-culture was positive in all bacterial meningitis patients; those with aseptic meningitis were negative. Bacteria were $S$. pneumoniae in 22 patients 
(55\%), N. meningitides in one $(2.5 \%), H$. influenzae in $12(30 \%)$, Klebsiella in $2(5 \%)$ and Staph. aureus in 3 patients (7.5\%). This agreed with Afifi et al. (2007) who found that $S$. pneumoniae was an introduced cause of bacterial meningitis in Egyptian adults.

In the present study, the bacterial patients had a higher value of CSF and serum TNF $\alpha$ at admission than aseptic patients with significant difference $(\mathrm{p}<0$. 001). This result agreed with others (Prasad et al, 2011; Panato et al, 2012; Zhao et al, 2012). The best cut-off value of TNF $\alpha$ for early diagnosis of bacterial meningitis was more than 275 and less than $700 \mathrm{ng} / \mathrm{ml}$. Panato et al. (2012) reported $80.5 \%$ sensitivity of CSF-TNF $\alpha$ and $94.9 \%$ specificity at a cut-off level of $71.7 \mathrm{ng} / \mathrm{ml}$, Zhao et al. (2012) reported 95\% $\& 92 \%$ at a cut-off level of $59.4 \mathrm{ng} / \mathrm{ml}$. Prasad et al. (2011) reported $94.7 \%$ and 54.3\% at optimum cutoff level of $79.7 \mathrm{ng} / \mathrm{ml} \mathrm{re-}$ spectively. Bociąga-Jasik et al. (2012) concluded that proinflammatory cytokines in CSF added in a differential diagnosis, and a high concentration might be a sensitive and specific marker of a bacterial etiology of neuroinfection and that concentrations more than $75.8 \mathrm{pg} / \mathrm{ml}$ differentiated between bacterial and viral meningitis with $100 \%$ sensitivity and specificity.

In the present study, the patients of the bacterial group had a higher values of CRP at admission than those of the aseptic group with high statistically significant difference between them $(\mathrm{p}<0.001)$, This result agreed with El- Kapany (2011); Viallon et al. (2011); Ibrahim et al. (2011) and Alkholi et al. (2011). In contrast, Makoo et al. (2010) reported that there was no significant difference in CRP between patients with bacterial and aseptic meningitis. This may be explained as the initial CRP level can occasionally be low in bacterial disease, especially in the early stages. CRP concentrations begin to rise between 6 and $12 \mathrm{~h}$ and reach a peak level only at 24 to $48 \mathrm{~h}$ (Mary et al, 2003).

\section{Conclusion}

Differentiation between septic and aseptic meningitis on clinical bases is difficult. No single test proved to be fully reliable in distinguishing bacterial from aseptic meningitis. Estimation of CSF-TNF $\alpha$ level with a cut off value more than 275 and less than $700 \mathrm{ng} / \mathrm{ml}$ is a good parameter for differentiation between septic and aseptic meningitis.

\section{References}

Abdel Ghani, SM, Hassan, EM, Masoud, S, et al, 2002: Rapid diagnosis of bacterial meningitis by latex agglutination test. J. Egypt. Pub. Hlth. Assoc.14, 1:31-44.

Abro, AH, Abdou, AS, Ustadi, AM, et al, 2009: CSF lactate level: A useful diagnostic tool to differentiate acute bacterial and viral meningitis. J. Pak. Med. Assoc, 59, 8:508-11.

Afifi, S, Wasfy, MO, Azab, MA, et al, 2007: Laboratory-based surveillance of patients with bacterial meningitis in Egypt (1998-2004). Eur. J. Clin. Microbiol. Infect. Dis. 26, 5:331-40.

Alkholi, UM, Abdel-Monem, N, Abdel-Azim, AA, et al, 2011: Serum Procalcitonin in Viral and Bacterial Meningitis. J. Glob. Infect. Dis. 3, 1:14-8.

Bociąga-Jasik, M, Garlicki, A, Cieśla, A, et al, 2012: The diagnostic value of cytokine and nitric oxide concentrations incerebrospinal fluid for the differential diagnosis of meningitis. Adv. Med. Sci. 57, 1:142-7.

Cassady, KA, Whitley, RJ, 1997: Pathogenesis and pathophysiology of viral infections of the Central Nervous System. In: Infections of the Central Nervous System. $2^{\text {nd }}$ ed. Scheld WN, Whitley RJ, Durack DT (eds). Philadelphia PA: Lippincott-Raven.

El Bashir, H, Laundy, M, Booy R, 2003: Diagnosis and treatment of bacterial meningitis. Arch. Dis. Child. 88:615-20.

El-Kapany, RA, 2011: Serum and CSF cortisol level in patients with meningitis. Egypt. J. Neurol. Psychiat. Neurosurg. 48, 4:391-7.

De O Papaiordanu, PM, Cadogan, SM, Ribeiro-Resende, $M$, et al, 1999: Bacterial meningitis in the elderly: an 8-year review of cases at a university hospital. Braz. J. Infect. Dis. 3:111-7.

Ginsberg, L, 2004: Difficult and recurrent meningitis. J. Neurol. Neurosurg. Psychiat. 75, 1: S16-21. 
Gorse, GJ, Thrupp, LD, Nudelman, KL, et al, 1998: Bacterial meningitis in the elderly. Arch. Int. Med. 144:1603-7.

Huy, NT, Thao, TH, Diep, TN, et al, 2010: Cerebrospinal fluid lactate concentration to distinguish bacterial from aseptic meningitis: a systemic review and meta-analysis. Crit. Care 14: R240-6.

Ibrahim, KA, Abdel-Wahab, AA, Ibrahim, A S, 2011: Serum procalcitonin in patients with acute meningitis: a comparison with blood leukocyte count and C-reactive protein. JPMA, 61: 346.

Makoo, ZB, Soltani, HR, Hasani, A, et al, 2010: Diagnostic value of serum and cerebrospinal fluid procalcitonin in differentiation bacterial from aseptic meningitis. Am. J. Infect. Dis. 6, 4:93-7.

Martin, C, Burdon, PCE, Bridger, G, et al, 2003: The balance between chemokines acting via CXCR4 and CXCR2 determines the release of neutrophils from the bone marrow and their return following senescence. Immunity, 19:58393.

Mary, R, Veinberg, F, Couderc, R, 2003: Acute meningitis, acute phase proteins and procalcitonin. Ann. Biol. Clin. 61:127-37.

Norman, DC, 2000: Fever in the elderly. Clin. Infect. Dis. 31:148-51.

Oberhoffer, M, Stonans, I, Russwurm, S, et al, 1999: Procalcitonin expression in human peripheral blood mononuclear cells and its modulation by lipopolysaccharides and sepsis-related cytokines in vitro. J. Lab. Clin. Med. 134:49-55.

Østergaard, C, Benfield T, 2009: Macrophage migration inhibitory factor in cerebrospinal fluid from patients with central nervous system infection. Crit. Care 13:R101.

Panato, AP, Tomasi, LT, Simon, CS, et al, 2012: Meta-analysis identifies tumor necrosis factor-alpha and interleukin-1 beta as diagnostic biomarkers for bacterial and aseptic meningitis. Curr. Neurovasc. Res. 11, 4:340-8.

Parasuraman, TV, Frenia, K, Romero, J, 2001: Enteroviral meningitis. Cost of illness and considerations for the economic evaluation of potential therapies. Pharmacoeconomics19:3-12. Prasad, R, Kapoor, R, Srivastava, R, et al, 2011: TNF- $\alpha$, IL- 6 , and IL- 8 in children with bacterial meningitis. Pediatr. Neurol. 50, 1:60-5 Raymond J, 2000: Epidemiology of nosocomial infections in pediatrics. Pathol/ Biol. 48:879-84.
Sáez-Llorens, X, McCracken, GH, 2003: Bacterial meningitis in children. Lancet 361, 9375: 2139-48.

Scarborough, M, Thwaites, G, 2008: The diagnosis and management of acute bacterial meningitis in resource-poor settings. Lancet Neurol. 7, 7:637-48

Straus, SE, Thorpe, KE, Holroyd-Leduc, J, 2006: How do I perform a lumbar puncture and analyze the results to diagnose bacterial meningitis? JAMA 296, 16:2012-22.

Swartz, MN, 2004: Bacterial meningitis--a view of the past 90 years. New Engl. J. Med. 351, 18: 1826-8.

Theilen, U, Wilson, L, Wilson G, et al, 2008: Management of invasive meningococcal disease in children and young people: Summary of SIGN guidelines. BMJ Clin. Res. 336, 7657: 1367-70.

Thwaites, DA, Tran, JJ, Breukels, MA, 2005: Analysis of emergency department management of suspected bacterial meningitis. Ann. Emerg. Med. 18:856-62.

Tokuda, V, 2000: Bacterial versus viral meningitis: Comparison of old and new clinical prediction model. Crit. Care 4:180-183.

Tokuda, Y, Koizumi, M, Stein, GH, et al, 2009: Identifying low-risk patients for bacterial meningitis in adult patients with acute meningitis. Int. Med. 48: 537-43.

Tunkel, AR, Hartman, BJ, Kaplan, SL, et al, 2004: Practice guidelines for the management of bacterial meningitis. Clin. Infect. Dis. 39, 9:1267-84.

Van De Beek, D, De Gans, J, Tunkel, AR, et al, 2006: Community acquired bacterial meningitis in adults. N. Engl. J. Med. 354, 1:44-53.

Van den Bos, F, Terken, M, Yoma, L, et al, 2005: Bacterial meningitis and miliary tuberculosis in young children. Trop. Med. Int. Hlth. 9:309-13.

Viallon, A, Desseigne, N, Marjollet, $\mathbf{O}$, et al, 2011: Meningitis in adult patients with a negative direct cerebrospinal fluid examination: value of cytochemical markers for differential diagnosis. Crit. care, 15, 3:R136-9.

Wise, R, Hart, T, Cars, O, et al, 1998: Antimicrobial resistance. Is a major threat to public health. BMJ 317:609-10

Zhao, J, Zhang, J, Kwon, S, et al, 2012: Tumor necrosis-factor $\alpha$ level in cerebrospinal fluid for bacterial and aseptic meningitis: a diagnostic metaanalysis. Eur. J. Neurol. 21, 8:1115-23. 